\title{
The potential impact and cost-effectiveness of tobacco reduction strategies for tuberculosis prevention in Canadian Inuit communities
}

\author{
Dieynaba S. N'Diaye ${ }^{1,2,3}$, Ntwali Placide Nsengiyumva $^{1,2,3}$, Aashna Uppal $^{1,2,3}$, Olivia Oxlade ${ }^{1,2,3}$, \\ Gonzalo G. Alvarez ${ }^{4,5}$ and Kevin Schwartzman ${ }^{1,2,3^{*}}$ iD
}

\begin{abstract}
Background: Tuberculosis (TB) remains a significant public health problem in Canadian Inuit communities. In 2016, Canadian Inuit had an incidence rate 35 times the Canadian average. Tobacco use is an important risk factor for TB, and over $60 \%$ of Inuit adults smoke. We aimed to estimate changes in TB-related outcomes and costs from reducing tobacco use in Inuit communities.

Methods: Using a transmission model to estimate the initial prevalence of latent TB infection (LTBI), followed by decision analysis modelling, we conducted a cost-effectiveness analysis that compared the current standard of care for management of TB and LTBI without additional tobacco reduction intervention (Status Quo) with (1) increased tobacco taxation, (2) pharmacotherapy and counselling for smoking cessation, (3) pharmacotherapy, counselling plus mass media campaign, and (4) the combination of all these. Projected outcomes included the following: TB cases, TB-related deaths, quality-adjusted life years (QALYs), and health system costs, all over 20 years.
\end{abstract}

Results: The combined strategy was projected to reduce active TB cases by $6.1 \%$ (95\% uncertainty range 4.9-7.0\%) and TB deaths by $10.4 \%$ (9.5-11.4\%) over 20 years, relative to the status quo. Increased taxation was the only costsaving strategy.

Conclusions: Currently available strategies to reduce commercial tobacco use will likely have a modest impact on TB-related outcomes in the medium term, but some may be cost saving.

Keywords: Cost-effectiveness, Decision analysis, Tuberculosis, Tobacco, Inuit

\section{Background}

Tuberculosis (TB) incidence in Canada has been declining in recent years, to 4.8 cases per 100,000 population in 2016 [1]. Incidence in the Canadian-born non-Indigenous population has declined steadily, but rates remain substantially higher in Indigenous Canadians [1, 2]. A substantial decline in $\mathrm{TB}$ incidence was observed in Canadian Inuit communities from the 1960s

\footnotetext{
* Correspondence: kevin.schwartzman@mcgill.ca

${ }^{1}$ Montreal Chest Institute, Montreal, Quebec, Canada

${ }^{2}$ Respiratory Epidemiology and Clinical Research Unit, Centre for Outcomes Research and Evaluation, Research Institute of the McGill University Health Centre, 1001 boulevard Décarie, Room D05.2511, Montreal, Quebec H4A 3J1, Canada

Full list of author information is available at the end of the article
}

through the 1980s [2]. However, there has been a resurgence in recent years [2]. For example, in 2016, Canadian Inuit had a TB incidence rate of 170 per 100,000 population [1].

TB programs in Inuit communities face unique environmental, health system, and contextual challenges, including geographic distance, but notably a history of forced separation of persons with TB, and of culturally insensitive health care in the context of colonialism [3]. However, these are not necessarily the only factors contributing to high TB incidence; it is pertinent to consider other potential contributing factors such as tobacco use.

A joint report from the World Health Organization (WHO) and the International Union Against $\mathrm{TB}$ and

(c) The Author(s). 2019 Open Access This article is distributed under the terms of the Creative Commons Attribution 4.0 International License (http://creativecommons.org/licenses/by/4.0/, which permits unrestricted use, distribution, and reproduction in any medium, provided you give appropriate credit to the original author(s) and the source, provide a link to the Creative Commons license, and indicate if changes were made. The Creative Commons Public Domain Dedication waiver (http://creativecommons.org/publicdomain/zero/1.0/) applies to the data made available in this article, unless otherwise stated. 
Lung Disease concluded that exposure to tobacco smoke was significantly associated with TB [4]. A modelling study projected that globally, with no improvements in tobacco reduction, smoking would lead to 18 million excess TB cases and 40 million excess TB deaths between 2010 and 2050 [5]. A systematic review identified substantial increases in risks of latent TB infection (LTBI), active TB, and TB-related death associated with smoking $[6,7]$.

In 2014, Nunavut had the highest proportion of commercial tobacco smokers of all Canadian provinces and territories, with $62 \%$ of the population aged over 12 estimated to be current smokers [8]. Among Indigenous adults more specifically, Inuit have the highest smoking prevalence [9]. It is therefore pertinent to consider potential benefits of decreased tobacco use, with respect to TB-related morbidity and mortality. In this modelling study, we examine the potential impact of several different evidence-based approaches to reduce tobacco consumption in Canadian Inuit communities. Strategies considered include (1) increased taxation; (2) pharmacotherapy and counselling; (3) pharmacotherapy, counselling, and mass media; and (4) the combination of all these [10-12]. We predict the impact of these strategies on TB-related health outcomes and attendant costs and cost-effectiveness.

\section{Methods}

\section{Model overview}

Dynamic model

Due to the high rates of prior TB exposure in the Inuit population, we first developed and validated a dynamic model that reflects TB epidemiology in Inuit communities in recent decades. Some key pathogenetic values (the contact rate, rapid progression from latent infection to active disease, and protective immunity from previous infection) were also refined and calibrated using this initial dynamic model (Additional file 1: Figure S1), based on observed epidemiologic data from Northern Canada from relevant time periods [13-15].

Four different phases of the TB epidemic were simulated. The first phase involved seeding the model, which corresponds to the historic introduction of the first infectious TB case into a fully susceptible population; this was followed by simulation over several decades to attain equilibrium where TB incidence and smoking prevalence were stable [16]. We used reported observations from this period to estimate the beta parameter (the rate of effective contact between infectious and non-infectious persons per unit of time). We considered that this first phase ended in 1948.

The second phase of the simulation covered the period 1948-1967. In this period, TB incidence declined and smoking prevalence was documented to be stable [16]. Antibiotic use was limited. However, living conditions began to improve, and this was captured by reduction in the beta parameter [17]. In order to calibrate the rate at which the beta declined, we used documented TB incidence and annual risk of infection (ARI) surveys from the Canadian Eastern Arctic [18, 19]. The first two phases marked the period before widespread antibiotic use in Arctic Canada. The third phase covered a period of decline in TB incidence and smoking prevalence from 1967 to 2000, while the fourth phase captured a period of increasing TB incidence from 2000 to 2017 (Additional file 1: Figure S2). It is early in the third phase that current, standard TB-related interventions (i.e., active case finding, smear and culture-based diagnosis, modern drug treatment and INH prophylaxis) were widely adopted. The model was calibrated during this period of declining TB incidence (1967-2000) using observed incidence and ARI [19].

We continued the calibration during 2000-2017, a period that included outbreaks of TB in Nunavut and Nunavik $[20,21]$. At the end of the dynamic simulation in 2017, key model outputs such as population distribution in each TB-related health state and other model parameters such as the annual risk of infection were stratified by smoking status. These parameters were then used to populate the Markov decision analysis model used to predict outcomes and costs from 2017 onward.

\section{Decision analysis model}

We then developed a Markov decision analysis model using TreeAge Pro software (TreeAge Software Inc., Williamstown, MA), to predict future health outcomes and costs after implementation of the tobacco reduction strategies. These strategies had been highlighted by community, public health, and academic informants working in Nunavut.

The cost effectiveness model simulated a hypothetical cohort of Canadian Inuit with median age 20 years, reflecting the age structure of this population [22], starting in 2017 [23, 24]. Health system costs relating to both $\mathrm{TB}$ and tobacco interventions and health outcomes including TB incidence, TB-related death, and quality-adjusted life-years (QALYs) were projected over 20 years with either the status quo or each of the different tobacco reduction interventions. A discount rate of $3 \%$ was applied to all projected future outcomes. A simplified representation of the decision analysis model is shown in Additional file 1: Figure S3.

\section{Data inputs for the decision analysis model TB pathogenetic and epidemiologic parameters}

Key parameters related to TB pathogenesis, epidemiology, and treatment are shown in Table 1. Additional detail is provided in the Additional file 1. 
Table 1 Decision analysis model parameters related to the natural history, epidemiology, and treatment of LTBI and TB

\begin{tabular}{|c|c|c|}
\hline \multicolumn{2}{|l|}{ Estimates } & \multirow[t]{2}{*}{ Reference } \\
\hline Probabilities & Probability $(\%)^{*}$ & \\
\hline -Probability of diagnosing LTBI & 25 & Assumption \\
\hline -Probability of completing LTBI treatment among those who start it & 70.8 & [69] \\
\hline - Probability of reactivation of longstanding LTBI to TB disease (non-smokers) & 0.05/year & [70-72] \\
\hline -Probability of rapid progression following TB infection (non-smokers)** & $4.5 /$ year for 2 years & Dynamic model $\left.\right|^{\#}$ \\
\hline -Probability of diagnosing active disease & 90 & Assumption \\
\hline -Probability of spontaneous resolution of untreated TB disease & 25 & [16] \\
\hline -Probability of relapse following spontaneously resolved TB & 2.5 & {$[16,73]$} \\
\hline -Probability of dying from untreated TB & 19/year & {$[74,75]$} \\
\hline -Probability of relapse after treated TB disease in first year & 1.5 & [76] \\
\hline -Protective immunity from previous TB disease & 55 & Dynamic model $\left.\right|^{\#}$ \\
\hline QALYs for LTBI and active TB & Value (range) & \\
\hline -Utility score for individual with active disease (treated) & $0.85(0.70-0.90)$ & [40] \\
\hline - Utility score for individual with active disease (untreated) & $0.68(0.65-0.72)$ & [39] \\
\hline -Utility score for individual with latent infection, during treatment & $0.97(0.95-1.00)$ & [40] \\
\hline -Utility score for individual with latent infection (untreated) & 1 & Assumption $^{\dagger}$ \\
\hline
\end{tabular}

INH isoniazid, LTBI latent tuberculosis infection, QALYS quality-adjusted life-years

*Probabilities are one-time percentages, unless stated otherwise

${ }^{* *}$ After 2 years, risk of developing active TB falls to $0.05 \%$ annually

${ }^{\dagger}$ Persons with LTBI are asymptomatic

"Calibrated in dynamic model

\section{Tobacco use as a risk factor for TB}

The effects of smoking on the pathogenesis of TB were obtained from two sources: (1) a systematic review which reported a relative risk of acquiring $\mathrm{TB}$ infection of 1.9 (95\% CI 1.6-2.3) comparing smokers with non-smokers and a relative risk of death from TB of 2.6 (95\% CI 1.8-3.6) for smokers compared to non-smokers [6] and (2) a modelling study by the same authors that estimated the relative risk of developing active TB conditional on prior infection $(\mathrm{RR}=1.5 ; 95 \%$ CI $1.3-1.7)$.

\section{Tobacco reduction strategies}

There are several effective tobacco reduction measures recommended by the WHO Framework Convention on Tobacco Control $[25,26]$. Of these, we considered four effective and widely used strategies. Evidence regarding their feasibility, acceptability, and effectiveness in Indigenous communities has also been reviewed by Chamberlain et al. [27] and Minichiello et al. [28]. Details are provided in Table 2 and the Additional file 1. All scenarios were compared to a status quo scenario that included the current standard of care for TB management, described above, as well as the background smoking cessation rate. Historical data from the Canadian Inuit population indicate a steady decline in smoking rates, at an average of $1.2 \%$ per year between 1967 and 2000 [8, 29-37]. After 2000, smoking prevalence began to level off and was 62\% in 2013 as reported by Statistics Canada [8]. To inform smoking trends after 2000, we used data from Nunavut which showed a continued decrease in smoking, but at a lower average rate of $0.8 \%$ annually [38]. We assumed that in the status quo scenario, current approaches including the level of taxation would remain unchanged for the duration of the analysis, as would current smoking cessation rates. The annual rates of decline shown for the various tobacco reduction interventions incorporate this background level of smoking cessation. We assumed that once smokers became non-smokers, they then faced the same TB-related risks as never-smokers.

\section{Health utilities}

We used health utility scores based on the time spent with or without active TB or latent TB infection to estimate QALYs. As our model only considered health outcomes related to TB, our QALY estimates included only those related to TB health states and not to other conditions related to smoking. For untreated active TB, we used a utility weight of $0.68(0.65-0.72)$ [39]; we used a utility weight of $0.85(0.70-0.90)$ for treated active TB, both obtained from Canadian studies [40]. For untreated LTBI, we assumed a utility weight of 1 and used a utility weight of 0.97 for those undergoing LTBI treatment, also based on Canadian data [40]. 
Table 2 Tobacco reduction strategies

\begin{tabular}{|c|c|c|c|c|}
\hline Scenario name & Brief description of strategy & $\begin{array}{l}\text { Expected reduction in smoking } \\
\text { prevalence* }^{*}\end{array}$ & $\begin{array}{l}\text { Duration of intervention } \\
\text { and its effect }\end{array}$ & Reference \\
\hline $\begin{array}{l}\text { Pharmacotherapy } \\
\text { and counselling }\end{array}$ & $\begin{array}{l}\text { Pharmacotherapy intervention to stop } \\
\text { smoking comprised of } 12 \text { weeks nicotine } \\
\text { replacement therapy (NRT) and } \\
\text { varenicline medication. Group and } \\
\text { individual counselling was offered to } \\
\text { participants to enhance odds of quitting. } \\
\text { Content and duration of counselling } \\
\text { sessions were obtained from a } \\
\text { meta-analysis of smoking cessation } \\
\text { interventions with individuals undergoing } \\
\text { treatment or recovery and dosage of } \\
\text { varenicline and NRT prescriptions } \\
\text { were modelled as per Inuit and } \\
\text { Canadian standards. }\end{array}$ & $1.5 \%$ per year for 3 years & $\begin{array}{l}\text { One time opportunity for smokers to } \\
\text { join pharmacotherapy and counselling } \\
\text { programs. Benefit was assumed to last } \\
\text { for } 3 \text { years (i.e., smoking prevalence } \\
\text { falls at an annual rate of } 1.5 \% \text { for } 3 \\
\text { consecutive years). Beyond this period } \\
\text { the prevalence declines at the } \\
\text { background rate of } 0.8 \% \text { annually. }\end{array}$ & {$[46,77,78]$} \\
\hline $\begin{array}{l}\text { Pharmacotherapy, } \\
\text { counselling and } \\
\text { mass media }\end{array}$ & $\begin{array}{l}\text { Pharmacotherapy and counselling } \\
\text { components of this strategy were similar } \\
\text { to the above strategy. We used pooled } \\
\text { risk ratios for cessation from two } \\
\text { randomized trials involving Indigenous } \\
\text { people in Australian communities } \\
\text { receiving national tobacco campaigns } \\
\text { supplemented by other Indigenous } \\
\text { specific campaigns such as } \\
\text { "Break the chain". }\end{array}$ & $1.9 \%$ per year for 3 years & $\begin{array}{l}\text { One time opportunity for smokers to } \\
\text { join pharmacotherapy and counselling } \\
\text { programs accompanied by a mass } \\
\text { media campaign. Benefit was assumed } \\
\text { to last for } 3 \text { years (i.e., smoking } \\
\text { prevalence falls at an annual rate of } \\
1.9 \% \text { for } 3 \text { consecutive years). Beyond } \\
\text { this period the prevalence declines at } \\
\text { the background rate of } 0.8 \% \text { annually. }\end{array}$ & {$[49]$} \\
\hline $\begin{array}{l}\text { Increased taxation } \\
\text { on commercial } \\
\text { cigarettes }\end{array}$ & $\begin{array}{l}\text { A legislative approach to commercial } \\
\text { tobacco control through increased } \\
\text { taxation which has no associated costs } \\
\text { from the perspective of the healthcare } \\
\text { system. To measure the impact of this } \\
\text { policy change vis-à-vis commercial } \\
\text { cigarette demand; we used reported } \\
\text { price elasticity of demand (i.e., the extent } \\
\text { to which cigarette use falls or rises after } \\
\text { increases or decreases in price) }\end{array}$ & $\begin{array}{l}7 \% \text { after } 3 \text { years increasing } \\
\text { to } 14 \% \text { after } 10 \text { years }^{\dagger}\end{array}$ & $\begin{array}{l}\text { One time } 25 \% \text { increase in tobacco } \\
\text { taxation was assumed to have greater } \\
\text { immediate effect in the first } 3 \text { years } \\
\text { and the effect would then decline over } \\
\text { time (i.e., smoking prevalence } \\
\text { decreases by } 7 \% \text { over } 3 \text { years, and after } \\
10 \text { years it decreases by a total of } 14 \% \text { ). } \\
\text { Beyond this period the prevalence } \\
\text { declines at the background rate of } \\
0.8 \% \text { annually. }\end{array}$ & {$[12,63,79,80]$} \\
\hline $\begin{array}{l}\text { All strategies } \\
\text { (Taxation + mass media } \\
+ \text { pharmacotherapy } \\
\text { + Counselling) }\end{array}$ & $\begin{array}{l}\text { Multifaceted strategy combining all } \\
\text { the above strategies: the measure } \\
\text { of effect of reduction in smoking } \\
\text { prevalence is derived from the effect } \\
\text { of increased taxation multiplied } \\
\text { by } 3 \text {-year effect (risk ratio) of } \\
\text { pharmacotherapy combined } \\
\text { with mass media }\end{array}$ & $\begin{array}{l}5.6 \% \text { annually for } 3 \text { years } \\
\text { and } 2.6 \% \text { annually for } \\
\text { subsequent } 7 \text { years }\end{array}$ & $\begin{array}{l}5.6 \% \text { annual reduction in smoking } \\
\text { prevalence for the first } 3 \text { years } \\
\text { followed by } 2.6 \% \text { annual reduction } \\
\text { up to year } 10 \text { after one-time } \\
\text { interventions. Beyond this period } \\
\text { the prevalence declines at the } \\
\text { background rate of } 0.8 \% \\
\text { annually. }\end{array}$ & {$[77,78,81]$} \\
\hline
\end{tabular}

*This table presents annual rates of reduction in smoking prevalence resulting from once off interventions of pharmacotherapy and/or mass media whose effect lasts 3 years

${ }^{t}$ The effect of a once off $25 \%$ taxation increase on smoking prevalence is presented at year 3 and year 10 , beyond this period, prevalence declines at the background rate of $0.8 \%$ annually

\section{Costs}

Health system costs for active and latent TB Where possible, TB-related health system costs were obtained from published sources from Nunavut, Canada. These included costs related to TB diagnosis, hospitalization, treatment (drug costs and administration), and treatment-related adverse events. Diagnostic costs related to active TB disease included chest radiography, sputum analysis, and hospitalization in situations when a person presented with symptoms suggestive of TB. The management of active $\mathrm{TB}$ also included the cost of transfers to Ottawa for patients with complications and/ or complex medical situations (estimated at $4 \%$ of active TB cases) $[41,42]$. Diagnostic costs related to LTBI included physical examination, tuberculin skin test (TST), and chest X-ray (CXR) for those who are TST positive [41-43]. Costs were adjusted to 2017 Canadian dollars, with details provided in the Additional file 1 [44]. Selected cost estimates are included in Table 3.

Costs related to tobacco reduction interventions Pharmacotherapy doses and costs were derived from Quebec and Nunavut health schemes, where 12 weeks of nicotine replacement therapy (NRT), including patches and chewing gum, is prescribed through government health plans [45].

A meta-analysis of smoking cessation interventions by Prochaska et al. was used to obtain the number and duration of pharmacotherapy counselling sessions [46]. The mean number of counselling sessions offered was 12 , with each session lasting between $5 \mathrm{~min}$ and $2 \mathrm{~h}$ (mean $=42$ 
Table 3 TB-related health system costs (2017 Canadian \$)

\begin{tabular}{|c|c|c|c|}
\hline & Value & Range & Reference \\
\hline \multicolumn{4}{|c|}{ Health system costs (including material and health care worker time/salary) } \\
\hline -Tuberculin skin test & $\$ 18.22$ & & {$[82]$} \\
\hline$\cdot$ INH (9-month regimen) & $\$ 182.01$ & & {$[83]$} \\
\hline -Major adverse reaction to Isoniazid & $\$ 14,937$ & & {$[82]$} \\
\hline -Chest X-ray & $\$ 68.00$ & & {$[84]$} \\
\hline -Three sputum samples analysis (when results are negative) & $\$ 29.34$ & & Dynacare \\
\hline -Three sputum samples analysis (when results are positive) & $\$ 80.79$ & & Dynacare \\
\hline -Spontaneous sputum production & $\$ 3.52$ & $(2.65-4.41)$ & {$[41]$} \\
\hline -Sputum induction & $\$ 96.84$ & & {$[42]$} \\
\hline •Xpert ${ }^{\oplus}$ MTB/RIF test for one individual (1 sample) & $\$ 134.40$ & & {$[41]$} \\
\hline -Standard 6 month TB medication regimen ${ }^{*}$ & $\$ 640.84$ & & [83] \\
\hline
\end{tabular}

INH isoniazid, NRT nicotine replacement therapy

*The cost includes vitamin B6

min, standard deviation $=33 \mathrm{~min}$ ). The hourly wage of a nurse in Nunavut [41] was used to calculate the total cost of counselling sessions. Key costs and assumptions associated with tobacco reduction interventions are provided in Table 4.

Mass media influence smokers depending on the scale of the campaigns. The US Centers for Disease Control and Prevention (CDC) have recommended \$1.69 (\$1-\$3) expenditure per capita for mass-reach health communication interventions to be effective [47]. Based on these recommendations, after accounting for inflation, \$2.05 per person was applied to the full population (smokers and non-smokers) for scenarios that included mass media campaigns [44].

\section{Sensitivity analysis}

\section{One and two-way analyses}

We performed univariate sensitivity analyses, varying key model probabilities and costs. We examined the most influential drivers of (a) TB incidence, (b) TB deaths, (c) QALYs gained, and (d) TB-related health system costs over 20 years. We also considered a scenario where the effect of tobacco-related interventions lasted 5 years, rather than three as we assumed in the primary analysis. According to the 2015 Canadian Tobacco, Alcohol and Drugs Survey (CTADS), 50\% of Canadian smokers attempted to quit smoking for at least $24 \mathrm{~h}$ [38]; we evaluated the effect of improved availability and use of pharmacotherapy interventions by increasing the proportion of smokers using pharmacotherapy to quit smoking to (a) $50 \%$ and (b) $75 \%$.

Probabilistic sensitivity analysis (PSA) was conducted by varying parameter estimates over their distributions (see Additional file 1: Table S2), and running 10,000 simulations to generate $95 \%$ uncertainty ranges (UR) for all model outputs.

\section{Results}

Base case

Compared with the status quo, the strategy combining all interventions was associated with an estimated 6.1\% (95\% UR 4.9-7.0\%) reduction in TB incidence over 20 years: $17.72 / 1000$ persons $(14.06 / 1000-22.32 / 1000)$ vs. 18.88/ 1000 persons $(14.81 / 1000-23.92 / 1000)$ for the status quo (Table 5). The same combined strategy was projected to reduce TB deaths by $10.4 \%$ (95\% UR 9.5-11.4\%). Increased taxation was projected to reduce $\mathrm{TB}$ incidence by $2.4 \%$ $(1.9-2.7 \%)$ and TB mortality by $3.8 \%(3.7 \%-4.4 \%)$. A similar pattern was observed in QALYs gained, with an estimated 1 QALY gained per 1000 community members when all interventions were combined. The increased taxation strategy was the only cost saving intervention. Estimated clinical outcomes and costs for all strategies and the status quo are shown in Table 5. For all tobacco reduction strategies other than taxation alone, costs of the interventions outweighed any associated savings in TB care (Table 6).

We calculated incremental cost-effectiveness ratios (ICERs) comparing the combined strategy with increased taxation alone. The estimated ICERs were (a) $\$ 256,022$ (95\% UR \$151,962-\$465,895) per TB case averted, (b) $\$ 1,522,952$ (95\% UR \$740,992-\$2,789,202) per TB death averted, and (c) \$164,369 (95\% UR \$76,252-\$252,203) per QALY gained.

\section{Sensitivity analyses}

Tornado diagrams (Additional file 1: Figure S4-S8) show that predicted TB incidence was most affected by the annual probability of reactivation of longstanding LTBI, while TB-related health system costs were primarily influenced by the cost and duration of hospitalization.

As shown in Table 7, increases in the proportion of smokers making quit attempts with pharmacotherapy had some impact on TB incidence and TB-related 
Table 4 Tobacco reduction costs (2017 Canadian \$)

\begin{tabular}{|c|c|c|c|}
\hline Costs associated with specific tobacco reduction scenarios & Component cost & $\begin{array}{l}\text { Per person cost } \\
\text { of intervention }\end{array}$ & Reference \\
\hline 1) Increased taxation ${ }^{\dagger}$ & & $\$ 0$ & \\
\hline \multicolumn{4}{|l|}{ 2) Pharmacotherapy and counselling } \\
\hline a. Unit cost of NRT chewing gum & $\$ 0.25$ & & [83] \\
\hline b. Number of doses of NRT chewing gum $(N)$ & 1008 & & [45] \\
\hline c. Cost of treatment with NRT chewing gum (a*b) & $\$ 254.32$ & & \\
\hline d. Unit cost of a nicotine patch & $\$ 2.68$ & & [83] \\
\hline e. Number of doses of nicotine patch $(N)$ & 84 & & [45] \\
\hline f. Cost of treatment with nicotine patch $\left(d^{*} e\right)$ & $\$ 225.00$ & & \\
\hline g. Cost of one varenicline $0.5 \mathrm{mg}$ pill & $\$ 1.72$ & & [83] \\
\hline h. Number of doses of varenicline $(N)$ & 317 & & \\
\hline i. Cost of treatment with varenicline $\left(\mathrm{g}^{*} \mathrm{~h}\right)$ & $\$ 544.29$ & & \\
\hline j. Number of counselling cessions & 12 & & [46] \\
\hline k. Duration of each counselling session & $42 \mathrm{~min}$ & & [46] \\
\hline I. Hourly Nurse wage & $\$ 81.39$ & & [41] \\
\hline m. Cost for complete counselling sessions $\left(j^{*} k^{*} \mid\right)$ & $\$ 683.68$ & & \\
\hline n. Total cost of Pharmacotherapy and counselling $(c+f+i+m)$ per person & $\$ 1707.29$ & & \\
\hline o. Proportion of smokers who made a quit attempt & $14.14 \%$ & & \\
\hline $\begin{array}{l}\text { Pro-rated mean cost of pharmacotherapy and counselling per smoker } \\
\text { ( } n^{*} \text { o: applied to all smokers in the model cohort) }\end{array}$ & & $\$ 241.41$ & \\
\hline \multicolumn{4}{|l|}{ 3) Pharmacotherapy, counselling and mass media } \\
\hline a. Total cost of pharmacotherapy and counselling & $\$ 1707.29$ & & \\
\hline b. Proportion of smokers who made a quit attempt & $19.8 \%$ & & \\
\hline c. Recommended per capita expenditure on mass media campaigns & $\$ 2.05$ & & [47] \\
\hline $\begin{array}{l}\text { Prorated mean cost of pharmacotherapy and counselling per smoker } \\
\left(a^{*} b+c\right) \text { : added to all smokers }\end{array}$ & & $\$ 339.78$ & \\
\hline 4) Multifaceted strategy — pharmacotherapy, counselling, mass media, and taxation & & $\$ 339.78$ & \\
\hline
\end{tabular}

${ }^{\dagger}$ Cost of taxation is incurred by the individual (hence no health system cost)

mortality, but a limited effect on quality-adjusted survival. On the other hand, extending the duration of effect of tobacco reduction interventions had little impact, since most of the TB-related benefit accrued early in the simulation. Indeed, offering pharmacotherapy and counselling annually for the full 20 years was associated with substantial cost increases, but little improvement in TB-related morbidity and mortality (Table 7). Sensitivity analysis of enhanced smoking cessation, either via repeated offers of pharmacotherapy and counselling or by greater uptake of these services, produced considerable reduction in smoking prevalence by the end of the simulation (see Additional file 1: Table S3) with limited changes in TB incidence.

Further sensitivity analysis results are presented in Additional file 1.

\section{Discussion}

Our analysis identified limited improvements in tuberculosis-related outcomes with enhanced tobacco reduction, despite the high prevalence of smoking, and well-documented links between tobacco use and TB. These findings reflect the modest effectiveness of existing tobacco reduction approaches, with health gains that become evident only in the longer term. Long-term quit rates remain suboptimal, and more effective smoking prevention and cessation alternatives are clearly needed. In sensitivity analysis, we projected further improvement in TB morbidity with increased uptake of pharmacotherapy for smoking cessation. Hence, more substantial reductions in tobacco use will likely bring both health and economic benefits with respect to tuberculosis in Inuit communities.

Of the strategies we evaluated, taxation involves no direct costs to the health system, so any resulting health gains also save money for the health care system. If increased taxation is indeed as effective in Northern Canada as elsewhere in reducing tobacco consumption, the cost-effectiveness of additional strategies (e.g., the addition of pharmacotherapy and counseling) is likely to be limited with respect to TB-related health outcomes. Taxation has 
Table 5 Projected costs and epidemiologic outcomes over 20 years

\begin{tabular}{|c|c|c|c|c|}
\hline Outcomes per 1000 persons & Cost (95\% UR) & TB incidence (95\% UR) & TB deaths (95\% UR) & QALYS (95\% UR) \\
\hline Status quo & $\$ 816,588(\$ 589,629-\$ 1,144,728)$ & $18.88(14.81-23.92)$ & $1.83(1.12-3.30)$ & $14,963.00(14,935.98-14,966.22)$ \\
\hline Increased taxation & $\$ 800,890(\$ 579,868-\$ 1,120,755)$ & $18.43(14.53-23.30)$ & $1.76(1.11-3.16)$ & $14,963.66(14,937.19-14,966.72)$ \\
\hline $\begin{array}{l}\text { Pharmacotherapy and } \\
\text { counselling }\end{array}$ & $\$ 955,921(\$ 726,763-\$ 1,279,070)$ & $18.71(14.71-23.68)$ & $1.80(1.12-3.25)$ & $14,963.25(14,936.45-14,966.41)$ \\
\hline $\begin{array}{l}\text { Pharmacotherapy, counselling, } \\
\text { and mass media }\end{array}$ & $\$ 1,012,812(\$ 782,975-\$ 1,333,469)$ & $18.62(14.65-23.56)$ & $1.79(1.11-3.22)$ & $14,963.40(14,936.71-14,966.52)$ \\
\hline $\begin{array}{l}\text { All [taxation + mass media + } \\
\text { pharmacotherapy + counselling] }\end{array}$ & $\$ 981,366(\$ 764,325-\$ 1,283,894)$ & $17.72(14.06-22.32)$ & $1.64(1.03-2.93)$ & $14,964.76(14,939.14-14,967.55)$ \\
\hline $\begin{array}{l}\text { Costs per person and ICERs_-status } \\
\text { quo as comparator }\end{array}$ & Incr. cost vs status quo & $\begin{array}{l}\text { Incr. cost per } \\
\text { TB case averted }\end{array}$ & $\begin{array}{l}\text { Incr. cost per TB } \\
\text { death averted }\end{array}$ & Incr. cost per QALY gained \\
\hline Status quo [comparator] & - & - & - & - \\
\hline Increased taxation & Saves $\$ 16(\$ 8-\$ 26)$ & Dominant & Dominant & Dominant \\
\hline $\begin{array}{l}\text { Pharmacotherapy and } \\
\text { counselling }\end{array}$ & $\$ 142(\$ 125-\$ 146)$ & $\begin{array}{l}\$ 837,464 \\
(\$ 527,624-\$ 1,462,565)\end{array}$ & $\begin{array}{l}\$ 4,990,117 \\
(\$ 2,495,571-\$ 8,928,090)\end{array}$ & $\begin{array}{l}\$ 542,594 \\
(\$ 259,691-\$ 812,827)\end{array}$ \\
\hline $\begin{array}{l}\text { Pharmacotherapy, counselling, } \\
\text { and mass media }\end{array}$ & $\$ 200(\$ 175-\$ 206)$ & $\begin{array}{l}\$ 760,387 \\
(\$ 478,141-\$ 1,330,478)\end{array}$ & $\begin{array}{l}\$ 4,530,453 \\
(\$ 2,264,728-\$ 8,115,767)\end{array}$ & $\begin{array}{l}\$ 492,482 \\
(\$ 235,705-\$ 738,813)\end{array}$ \\
\hline $\begin{array}{l}\text { All [taxation + mass media + } \\
\text { pharmacotherapy }+ \text { counselling] }\end{array}$ & $\$ 181(\$ 157-\$ 196)$ & $\begin{array}{l}\$ 142,907 \\
(\$ 78,263-\$ 271,386)\end{array}$ & $\begin{array}{l}\$ 852,009 \\
(\$ 398,407-\$ 1,594,941)\end{array}$ & $\begin{array}{l}\$ 93,717 \\
(\$ 41,304-\$ 147,677)\end{array}$ \\
\hline $\begin{array}{l}\text { ICERs per person-increased } \\
\text { taxation as a comparator }\end{array}$ & Incr. cost vs Increased taxation & $\begin{array}{l}\text { Incr. cost per TB case } \\
\text { averted }\end{array}$ & $\begin{array}{l}\text { Incr. cost per TB death } \\
\text { averted }\end{array}$ & Incr. cost per QALY gained \\
\hline Status quo & $\$ 16(\$ 8-\$ 26)$ & Dominated & Dominated & Dominated \\
\hline Increased taxation [comparator] & - & - & - & - \\
\hline $\begin{array}{l}\text { Pharmacotherapy and } \\
\text { counselling }\end{array}$ & $\$ 155(\$ 139-\$ 164)$ & Dominated & Dominated & Dominated \\
\hline $\begin{array}{l}\text { Pharmacotherapy, counselling, } \\
\text { and mass media }\end{array}$ & $\$ 212(\$ 192-\$ 222)$ & Dominated & Dominated & Dominated \\
\hline $\begin{array}{l}\text { All [taxation + mass media + } \\
\text { pharmacotherapy + counselling] }\end{array}$ & $\$ 180(\$ 154-\$ 195)$ & $\begin{array}{l}\$ 256,022 \\
(\$ 151,962-\$ 465,895)\end{array}$ & $\begin{array}{l}\$ 1,522,952 \\
(\$ 740,992-\$ 2,789,202)\end{array}$ & $\begin{array}{l}\$ 164,369 \\
(\$ 76,252-\$ 252,203)\end{array}$ \\
\hline
\end{tabular}

UR uncertainty range, ICER incremental cost-effectiveness ratio, Incr incremental Numbers in parentheses represent $95 \%$ UR i.e. uncertainty ranges

been shown to be effective in reducing smoking prevalence and smoking initiation in younger community members (15-24 years) who may be the most sensitive to tobacco price increases. Smoking prevalence is exceptionally high in this group among Inuit, and likewise, the TB epidemic has consistently involved young adults, making them a key group [14]. This is highly relevant to Inuit communities, where the median age is as low as 21 [22], and where $46 \%$ of those who smoke started by age $14[8,48]$. More generally, the strategies we considered have proven effective in Indigenous settings in Australia, the USA, and Canada [28, 49-52] and are among the measures recommended by the WHO Framework Convention on Tobacco Control $[25,26]$.

While some authors have projected improvements in tuberculosis morbidity related to reduced tobacco use [5], there are few cost-effectiveness analyses addressing the impact of specific tobacco reduction strategies on $\mathrm{TB}$ prevention. Kowada and colleagues evaluated the

Table 6 Projected health system and smoking interventions costs over 20 years

\begin{tabular}{llll}
\hline Outcomes per 1000 persons & Total cost & TB-related health system cost & Smoking intervention cost \\
\hline Status quo & $\$ 816,588$ & $\$ 816,588$ & - \\
Increased taxation & $\$ 800,890$ & $\$ 800,890$ & - \\
Pharmacotherapy and counselling & $\$ 955,921$ & $\$ 810,731$ & $\$ 145,190$ \\
Pharmacotherapy, counselling, and mass media & $\$ 1,012,812$ & $\$ 807,503$ & $\$ 205,309$ \\
All [taxation + mass media + pharmacotherapy + counselling] & $\$ 981,366$ & $\$ 776,057$ & $\$ 205,309$ \\
\hline
\end{tabular}


Table 7 Sensitivity analysis - projected costs and outcomes per 1000 population over 20 years

\begin{tabular}{|c|c|c|c|c|}
\hline Strategy & Cost & TB incidence & TB deaths & QALYs accrued \\
\hline \multicolumn{5}{|l|}{ Pharmacotherapy interventions' effectiveness lasts 5 years } \\
\hline Status quo-no new intervention & $\$ 816,588$ & 18.88 & 1.83 & $14,963.00$ \\
\hline Increased taxation & $\$ 800,890$ & 18.43 & 1.76 & $14,963.66$ \\
\hline Pharmacotherapy and counselling & $\$ 953,746$ & 18.65 & 1.79 & $14,963.33$ \\
\hline Pharmacotherapy, counselling, and mass media campaign & $\$ 1,009,480$ & 18.52 & 1.77 & $14,963.52$ \\
\hline Combination of all strategies & $\$ 977,469$ & 17.61 & 1.62 & $14,964.90$ \\
\hline \multicolumn{5}{|c|}{ Taxation (one time increase), pharmacotherapy, and mass media continued for 20 years } \\
\hline Status quo-no new intervention & $\$ 816,588$ & 18.88 & 1.83 & $14,963.00$ \\
\hline Increased Taxation & $\$ 800,890$ & 18.43 & 1.76 & $14,963.66$ \\
\hline Pharmacotherapy and counselling & $\$ 2,732,610$ & 18.48 & 1.77 & $14,963.48$ \\
\hline Pharmacotherapy, counselling, and mass media campaign & $\$ 3,444,542$ & 18.27 & 1.73 & $14,963.73$ \\
\hline Combination of all strategies & $\$ 3,047,175$ & 17.36 & 1.58 & $14,965.13$ \\
\hline \multicolumn{5}{|c|}{ Scenario where $50 \%$ of smokers attempt quitting and use pharmacotherapy services } \\
\hline Status quo-no new intervention & $\$ 816,588$ & 18.88 & 1.83 & $14,963.00$ \\
\hline Increased taxation & $\$ 800,890$ & 18.43 & 1.76 & $14,963.66$ \\
\hline Pharmacotherapy and counselling & $\$ 1,293,929$ & 17.83 & 1.66 & $14,964.42$ \\
\hline Pharmacotherapy, counselling, and mass media campaign & $\$ 1,288,847$ & 17.63 & 1.62 & $14,964.74$ \\
\hline Combination of all strategies & $\$ 1,226,645$ & 15.87 & 1.33 & $14,967.53$ \\
\hline \multicolumn{5}{|c|}{ Scenario where $75 \%$ of smokers attempt quitting and use pharmacotherapy services } \\
\hline Status quo-no new intervention & $\$ 816,588$ & 18.88 & 1.83 & $14,963.00$ \\
\hline Increased taxation & $\$ 800,890$ & 18.43 & 1.76 & $14,963.66$ \\
\hline Pharmacotherapy and counselling & $\$ 1,521,195$ & 16.97 & 1.52 & $14,965.59$ \\
\hline Pharmacotherapy, counselling, and mass media campaign & $\$ 1,512,916$ & 16.68 & 1.47 & $14,966.07$ \\
\hline Combination of all strategies & $\$ 1,433,675$ & 14.46 & 1.09 & $14,969.78$ \\
\hline
\end{tabular}

potential cost-effectiveness of pharmacotherapy in conjunction with screening for latent infection, among TB contacts who smoke [53] and concluded that smoking cessation interventions are likely cost-effective in the management of TB contacts in low-incidence countries.

Our study has several limitations. Most importantly, we did not consider health benefits, QALYs, and cost savings of reduced tobacco use beyond the TB context, which are of course well documented in other clinical settings [54-57]. In fact, integration of other benefits would further strengthen the argument for investment in smoking cessation and prevention. Though this analysis found modest improvements in TB morbidity, we estimated a $10 \%$ absolute reduction in smoking prevalence with the combined strategy. Of note, there is also evidence that smoking cessation interventions improve quit rates and quality of life among persons with $\mathrm{TB}$ [58-62]. On the other hand, there are lags between smoking cessation and many associated health benefits (e.g., reductions in lung cancer and coronary artery disease risks). We did not model such lags with respect to TB-associated risks, as at present there are no firm data in this regard. The systematic review and meta-analysis by Lin and colleagues identified some studies which indeed suggested persistent elevation of TB risks in former smokers [6]. This would further limit short-term improvements in TB-related health outcomes related to reduced tobacco use. The same may be true for concomitant alcohol use, which was a potential unadjusted confounder in some studies included in that meta-analysis.

While we had high-quality local data for TB-related health care costs, some cost estimates for tobacco reduction strategies had to be obtained elsewhere, as there were no such data from the Canadian Arctic. It is also possible that price elasticity for tobacco products may differ in the Arctic setting, meaning that tax increases may have greater or lesser effects than observed elsewhere. However, our base case estimate for price elasticity was obtained from a comprehensive review [63],

It is essential that any strategy to reduce tobacco use be concordant with the community's experience, culture, and values. Because of limited information, many model inputs unfortunately did not reflect Inuit-specific data or experience, though scenarios were vetted by community partners. If tobacco and $\mathrm{TB}$ reduction efforts are to be 
successful, they must reflect community-based programs to address upstream determinants, informed by members' experience and values [64]. Such programs may provide effective adjuncts or alternatives to TB-specific technical interventions, since they focus on prevention rather than enhanced diagnostic capacity. The relative isolation of many Northern communities also highlights the potential role of non-technical approaches to TB prevention. However, policymakers must also recognize that the benefits of reduced tobacco use for TB prevention will likely become apparent only very gradually.

\section{Conclusions}

Smoking prevention and cessation strategies are projected to have a modest impact on TB-related morbidity in Inuit communities in the short to medium term, but some may be cost saving. However, even small reductions in tobacco use may strengthen TB prevention efforts and provide gains in other health outcomes. Although we focused on a very specific Northern setting, our methods and findings are relevant to other areas where both tobacco use and TB are highly prevalent [65]. Other risk factors such as alcohol use, nutrition and food security, and housing conditions could also be considered [66-68].

\section{Additional file}

Additional file 1: Supplemental Methods and Results. (DOCX 849 kb)

\begin{abstract}
Abbreviations
CDC: Centers for Disease Control and Prevention; CTADS: Canadian Tobacco, Alcohol and Drugs Survey; CXR: Chest X-ray; ICER: Incremental costeffectiveness ratio; LTBI: Latent TB infection; NRT: Nicotine replacement therapy; PSA: Probabilistic sensitivity analysis; QALY: Quality-adjusted life year; TB: Tuberculosis; TST Test: Tuberculin skin test; UR: Uncertainty range; WHO: World Health Organization
\end{abstract}

\section{Acknowledgements}

The authors wish to acknowledge the assistance of Dr. Jordan Sugarman with initial literature and costing reviews. In addition, we wish to acknowledge the key guidance and input of the TAIMA-TB Steering Committee.

\section{Funding}

This research was funded by the Canadian Institutes of Health Research. The funding body played no role in the design of the study and collection, analysis, and interpretation of data.

\section{Availability of data and materials}

The datasets used and/or analysed during the current study are available from the corresponding author on reasonable request.

\section{Authors' contributions}

KS, GGA, and OO designed the study. DSN, NPN, AU, OO, and KS contributed equally to model development, data analysis, and interpretation. GGA contributed substantially to data interpretation. He provided information on measures of effect for smoking-related interventions, expertise on tuberculosis, and risk factors in Inuit communities, as well as community guidance and input through the TAIMA-TB Steering Committee. DSN and NPN prepared the initial manuscript drafts. All authors contributed to writing the manuscript and approved its final version.

\section{Ethics approval and consent to participate}

The need for ethical approval was waived as the study was a modelling study with no primary research component.

\section{Consent for publication}

Not applicable.

\section{Competing interests}

The authors declare that they have no competing interests.

\section{Publisher's Note}

Springer Nature remains neutral with regard to jurisdictional claims in published maps and institutional affiliations.

\section{Author details}

${ }^{1}$ Montreal Chest Institute, Montreal, Quebec, Canada. ${ }^{2}$ Respiratory Epidemiology and Clinical Research Unit, Centre for Outcomes Research and Evaluation, Research Institute of the McGill University Health Centre, 1001 boulevard Décarie, Room D05.2511, Montreal, Quebec H4A 3J1, Canada. ${ }^{3}$ McGill International Tuberculosis Centre, Montreal, Quebec, Canada. ${ }^{4}$ The Ottawa Hospital Research Institute, Ottawa, Ontario, Canada. ${ }^{5}$ Department of Medicine, Division of Respirology, The Ottawa Hospital and University of Ottawa, Ottawa, Ontario, Canada.

Received: 28 September 2018 Accepted: 15 January 2019

Published online: 04 February 2019

\section{References}

1. Vachon J, Gallant V, Siu W. La tuberculose au Canada, 2016. Relevé des maladies transmissibles au Canada. 2018;44(3/4):85-91.

2. Dehghani K, Lan Z, Li P, Michelsen SW, Waites S, Benedetti A, et al. Determinants of tuberculosis trends in six Indigenous populations of the USA, Canada, and Greenland from 1960 to 2014: a population-based study. Lancet Public Health. 2018. https://doi.org/10.1016/\$2468-2667(18)30002-1.

3. Møller $\mathrm{H}$. Tuberculosis and colonialism: current tales about tuberculosis and colonialism in Nunavut. J Aborig Health. 2010;6(1) https://journals.uvic.ca/ index.php/ijih/article/view/12344.

4. World Health Organization. A WHO/The Union monograph on TB and tobacco control: joining efforts to control two related global epidemics. In: Organization WH, editor. A WHO/the Union monograph on TB and tobacco control: joining efforts to control two related global epidemics. Geneva: World Health Organization; 2007;2007:5-34. http://www.who.int/iris/handle/ $10665 / 43812$

5. Basu S, Stuckler D, Bitton A, Glantz SA. Projected effects of tobacco smoking on worldwide tuberculosis control: mathematical modelling analysis. BMJ. 2011;343:d5506 http://www.bmj.com/content/bmj/343/bmj.d5506.full.pdf.

6. Lin $\mathrm{H}-\mathrm{H}$, Ezzati M, Murray M. Tobacco smoke, indoor air pollution and tuberculosis: a systematic review and meta-analysis. PLoS Med. 2007:4(1):e20 https://www.ncbi.nlm.nih.gov/pmc/articles/PMC1769410/pdf/pmed.0040020.pdf.

7. Lin H-H, Murray M, Cohen T, Colijn C, Ezzati M. Effects of smoking and solidfuel use on COPD, lung cancer, and tuberculosis in China: a time-based, multiple risk factor, modelling study. Lancet. 2008;372(9648):1473-83.

8. Statistics Canada. Smokers, by sex, provinces and territories (percent). 2016.

9. Boomer J. Building and sustaining partnerships: a resource guide to address non-traditional tobacco use. Health Canada First Nation and Inuit Health Branch; 2003.

10. Department of Health Human Services USA. Preventing tobacco use among young people: A report of the Surgeon General: US Department of Health and Human Services; 1994

11. Hopkins DP, Briss PA, Ricard CJ, Husten CG, Carande-Kulis VG, Fielding $J$ E, et al. Reviews of evidence regarding interventions to reduce tobacco use and exposure to environmental tobacco smoke. Am J Prev Med. 2001;20(2):16-66.

12. Levy DT, Chaloupka F, Gitchell J. The effects of tobacco control policies on smoking rates: a tobacco control scorecard. J Public Health Manag Pract. 2004;10(4):338-53 https://journals.lww.com/jphmp/Fulltext/2004/07000/ The_Effects_of_Tobacco_Control_Policies_on_Smoking.11.aspx.

13. Ellis E, Gallant V, Phypers M, Scholten D, Miron M. Tuberculosis in Canada, 2001: Health Canada, Population \& Public Health Branch, Centre for Infectious Disease Prevention \& Control, Tuberculosis Prevention \& Control; 2003 
14. Gallant V, Duvvuri V, McGuire M. Tuberculosis in Canada-summary 2015. Can Commun Dis Rep. 2017;43(3/4):77.

15. Gallant V, McGuire M, Ogunnaike-Cooke S. A summary of tuberculosis in Canada, 2013. Can Commun Dis Rep. 2015;41(S2):2.

16. Grzybowski S, Enarson DA. The fate of cases of pulmonary tuberculosis under various treatment programmes. Bull IUAT. 1978;53(2):70-5.

17. Barsh RL. Canada's Aboriginal peoples: social integration or disintegration. Can J Nativ Stud. 1994;14(1):1-46.

18. Grzybowski S, Dorken E. Tuberculosis in Inuit. Ecol Dis. 1983;2(2):145-8.

19. Grzybowski S, Styblo K, Dorken E. Tuberculosis in Eskimos. Tubercle. 1976; 57(4):S1-S58. https://doi.org/10.1016/0041-3879(76)90059-3.

20. MacDonald N, Hébert PC, Stanbrook MB. Tuberculosis in Nunavut: a century of failure. CMAJ. 2011;183(7):741-3.

21. Lee RS, Proulx J-F, Menzies D, Behr MA. Progression to tuberculosis disease increases with multiple exposures. Eur Respir J. 2016. https://doi.org/10. 1183/13993003.00893-2016 http://erj.ersjournals.com/content/48/6/1682.

22. Statistics Canada. Age distribution and median age of Inuit by area of residence - Inuit Nunangat, Canada, 2011. Ottawa: Statistics Canada; 2011. Report No

23. Statistics Canada. Nunavut, Inuit region, Nunavut (Code 640004) (table). National Household Survey (NHS) Aboriginal Population Profile. Ottawa: Statistics Canada; 2013. Report No

24. Statistics Canada. Nunavik, Inuit region, Quebec (Code 640002) (table). National Household Survey (NHS) Aboriginal Population Profile. Ottawa: Statistics Canada; 2013. Report No

25. World Health Organization. A WHO/The Union monograph on TB and tobacco control: joining efforts to control two related global epidemics. A WHO/the Union monograph on TB and tobacco control: joining efforts to control two related global epidemics 2007.

26. World Health Organization. The WHO Framework Convention on Tobacco Control. Geneva: World Health Organization; 2003. http://apps.who.int/iris/ bitstream/10665/42811/1/9241591013.pdf?ua=1

27. Chamberlain C, Perlen S, Brennan S, Rychetnik L, Thomas D, Maddox R, et al. Evidence for a comprehensive approach to Aboriginal tobacco control to maintain the decline in smoking: an overview of reviews among Indigenous peoples. Systematic Reviews. 2017;6(1):135. https://systematicreviewsjournal. biomedcentral.com/articles/10.1186/s13643-017-0520-9.

28. Minichiello A, Lefkowitz AR, Firestone M, Smylie JK, Schwartz R. Effective strategies to reduce commercial tobacco use in indigenous communities globally: a systematic review. BMC Public Health. 2016;16(1):21.

29. Beaudry PH. Pulmonary function survey of the Canadian Eastern Arctic Eskimo. Arch Environ Health. 1968;17(4):524-8.

30. Carrière G, Tjepkema M, Pennock J, Goedhuis N. Cancer patterns in Inuit Nunangat: 1998-2007. Int J Circumpolar Health. 2012;71(1):18581. http:// www.tandfonline.com/doi/pdf/10.3402/ijch.v71i0.18581?needAccess=true.

31. Millar WJ. Place of birth and ethnic status: factors associated with smoking prevalence among Canadians. Health Rep. 1992;4(1):7-24.

32. Millar WJ. Smoking prevalence in the Canadian Arctic. Arctic Med Res. 1990; 49:23-8.

33. Pickering J, Lavallee C, Hanley J. Cigarette smoking in Cree Indian school children of the James Bay region. Arctic Med Res. 1989;48(1):6-11.

34. Rode A, Shephard R. Lung function in Canadian Inuit: a follow-up study. Can Med Assoc J. 1984;131(7):741. https://www.ncbi.nlm.nih.gov/pmc/ articles/PMC1483593/pdf/canmedaj00369-0039.pdf.

35. Tait H. Aboriginal Peoples Survey, 2006: Inuit health and social conditions. Ottawa: Statistics Canada, Social and Aboriginal Statistics Division; 2008.

36. Statistics Canada. Canadian health characteristics, two year period estimates, by age group and sex, Canada, provinces, territories and health regions. 2017.

37. Interval C. Smoking, 2016 - Statistics Canada. Statistics Canada. Ottawa: 2017;2016(82-625-X). https://www.statcan.gc.ca/pub/82-625-x/2017001/ article/54864-eng.htm.

38. Canadian Tobacco Alcohol and Drugs (CTADS). Canadian Tobacco Alcohol and Drugs (CTADS). Summary of results for 2015. Health Canada. 2015 https://www.canada.ca/en/healthcanada/services/canadian-tobacco-alcoholdrugs-survey/2015-summary.html.

39. Guo N, Marra CA, Marra F, Moadebi S, Elwood RK, FitzGerald JM. Health state utilities in latent and active tuberculosis. Value Health. 2008;11(7): 1154-61.

40. Bauer M, Ahmed S, Benedetti A, Greenaway C, Lalli M, Leavens A, et al. Health-related quality of life and tuberculosis: a longitudinal cohort study. Health Qual Life Outcomes. 2015;13(1):65.
41. Oxlade O, Sugarman J, Alvarez GG, Pai M, Schwartzman K. Xpert ${ }^{\oplus}$ MTB/RIF for the diagnosis of tuberculosis in a remote Arctic setting: impact on cost and time to treatment initiation. PLoS One. 2016;11(3):e0150119 https:// www.ncbi.nlm.nih.gov/pmc/articles/PMC4798714/pdf/pone.0150119.pdf.

42. Sugarman J, Alvarez G, Schwartzman K, Oxlade O. Sputum induction for tuberculosis diagnosis in an Arctic setting: a cost comparison. Int J Tuberc Lung Dis. 2014;18(10):1223-30.

43. Khan K, Muennig P, Behta M, Zivin JG. Global drug-resistance patterns and the management of latent tuberculosis infection in immigrants to the United States. N Engl J Med. 2002;347(23):1850-9 http://www.nejm.org/doi/ pdf/10.1056/NEJMsa021099.

44. Bank of Canada. Inflation calculator, Bank of Canada. The Consumer Price Index, Statistics Canada. 2017.http://www.bankofcanada.ca/rates/related/ inflation-calculator/.

45. Pauktuutit Inuit Women of Canada. Facilitator's Guide, Atii! Reduce SecondHand Smoke. Canada: Pauktuutit Inuit Women of Canada; 2012. https://www. pauktuutit.ca/health/tobacco-cessation/atii-reduce-second-hand-smoke/.

46. Prochaska JJ, Delucchi K, Hall SM. A meta-analysis of smoking cessation interventions with individuals in substance abuse treatment or recovery. J Consult Clin Psychol. 2004;72(6):1144 https://cloudfront.escholarship.org/ dist/prd/content/qt0r8673wv/qt0r8673wv.pdf?t=Inrsdv.

47. King BA, Pechacek TF, Mariolis P. Best practices for comprehensive tobacco control programs, 2014. 2014.https://www.cdc.gov/tobacco/ stateandcommunity/best_practices/pdfs/2014/comprehensive.pdf

48. Health Canada. First Nations \& Inuit Health - Substance Use \& Treatment of Addictions - Tobacco. 2016. Report No.

49. Marley JV, Atkinson D, Kitaura T, Nelson C, Gray D, Metcalf S, et al. The Be Our Ally Beat Smoking (BOABS) study, a randomised controlled trial of an intensive smoking cessation intervention in a remote aboriginal Australian health care setting. BMC Public Health. 2014;14(1):32.

50. Eades SJ, Sanson-Fisher RW, Wenitong M, Panaretto K, D'Este C, Gilligan C, et al An intensive smoking intervention for pregnant Aboriginal and Torres Strait Islander women: a randomised controlled trial. Med J Aust. 2012;197(1):42-6.

51. Gould GS, Watt K, Stevenson L, McEwen A, Cadet-James Y, Clough AR. Developing anti-tobacco messages for Australian Aboriginal and Torres Strait Islander peoples: evidence from a national cross-sectional survey. BMC Public Health. 2014;14(1):250.

52. Carson KV, Brinn MP, Peters M, Veale A, Esterman AJ, Smith BJ. Interventions for smoking cessation in Indigenous populations. Cochrane Database Syst Rev. 2012;(1):CD009046. https://doi.org/10.1002/14651858.CD009046.pub2.

53. Kowada A. Cost-effectiveness of tobacco cessation support combined with tuberculosis screening among contacts who smoke. Int J Tuberc Lung Dis. 2015;19(7):857-63.

54. Siegel RL, Miller KD, Jemal A. Cancer statistics, 2016. CA Cancer J Clin. 2016; 66:7-30. https://doi.org/10.3322/caac.21332.

55. American Cancer Society. Cancer Facts \& Figures 2013. Atlanta: American Cancer Society; 2013. https://www.cancer.org/research/cancer-factsstatistics/all-cancer-facts-figures/cancer-facts-figures-2013.html.

56. Skaaby T, Taylor AE, Jacobsen RK, Paternoster L, Thuesen BH, Ahluwalia TS, et al. Investigating the causal effect of smoking on hay fever and asthma: a Mendelian randomization meta-analysis in the CARTA consortium. Sci Rep. 2017;7(1):2224 https://www.ncbi.n/m.nih.gov/pmc/articles/PMC5440386/pdf/ 41598_2017_Article_1977.pdf.

57. Schmidt CO, Watzke A-B, Schulz A, Baumeister SE, Freyberger HJ, Grabe H-J. The lifetime prevalence of mental disorders in north-eastern Germany. What is the influence of earlier mental morbidity on survey participation and prevalence estimates? Results from the SHIP-study. Psychiatr Prax. 2013;40(4): 192-9 https://www.thieme-connect.com/DOI/DOI?10.1055/s-0033-1343100.

58. Awaisu A, Mohamed MHN, Noordin NM, Muttalif AR, Aziz NA, Sulaiman SAS, et al. Impact of connecting tuberculosis directly observed therapy shortcourse with smoking cessation on health-related quality of life. Tob Induc Dis. 2012;10(1):2

59. Campbell I, Chaudhary R, Holdsworth G, Lyne O. Brief advice to tuberculosis patients in Nepal to stop smoking: a pilot study by the Britain Nepal Medical Trust. Int J Tuberc Lung Dis. 2014;18(12):1438-42.

60. Jeyashree K, Kathirvel S, Shewade HD, Kaur H, Goel S. Smoking cessation interventions for pulmonary tuberculosis treat-ment outcomes. Cochrane Database Syst Rev. 2014;5.

61. Kaur J, Sachdeva KS, Modi B, Jain DC, Chauhan LS, Dave P, et al. Promoting tobacco cessation by integrating'brief advice'in tuberculosis control programme. WHO South-East Asia J Public Health. 2013;2:28-33. 
62. Siddiqi K, Khan A, Ahmad M, Dogar O, Kanaan M, Newell JN, et al. Action to stop smoking in suspected tuberculosis (ASSIST) in Pakistan: a cluster randomized, controlled trial. Ann Intern Med. 2013;158(9):667-75.

63. Gallet CA, List JA. Cigarette demand: a meta-analysis of elasticities. Health Econ. 2002;12(10):821-35 https://doi.org/10.1002/hec.765.

64. Lönnroth K, Jaramillo E, Williams BG, Dye C, Raviglione M. Drivers of tuberculosis epidemics: the role of risk factors and social determinants. Soc Sci Med. 2009;68(12):2240-6.

65. World Health Organization. Companion handbook to the WHO guidelines for the programmatic management of drug-resistant tuberculosis. 2014.

66. Rehm J, Samokhvalov AV, Neuman MG, Room R, Parry C, Lönnroth K, et al. The association between alcohol use, alcohol use disorders and tuberculosis (TB). A systematic review. BMC Public Health. 2009;9(1):450.

67. Harries A, Lin Y, Satyanarayana S, Lönnroth K, Li L, Wilson N, et al. The looming epidemic of diabetes-associated tuberculosis: learning lessons from HIV-associated tuberculosis. Int J Tuberc Lung Dis. 2011;15(11):1436-45.

68. Frost WH. Risk of persons in familial contact with pulmonary tuberculosis. Am J Public Health Nations Health. 1933;23(5):426-32 https://www.ncbi.nIm. nih.gov/pmc/articles/PMC1558187/pdf/amjphnation00929-0022.pdf.

69. Alvarez GG, VanDyk DD, Aaron SD, Cameron DW, Davies N, Stephen N, et al. Taima (stop) TB: the impact of a multifaceted TB awareness and door-todoor campaign in residential areas of high risk for TB in lqaluit, Nunavut. PloS one. 2014;9(7):e100975.

70. Comstock GW, Edwards LB, Livesay VT. Tuberculosis morbidity in the US Navy: its distribution and decline 1, 2. Am Rev Respir Dis. 1974;110(5):572-80.

71. Nolan CM, Elarth AM. Tuberculosis in a cohort of Southeast Asian refugees. Am Rev Respir Dis. 1988;137:805-9.

72. Behr MA, Edelstein PH, Ramakrishnan L. Revisiting the timetable of tuberculosis. BMJ. 2018;362:k2738 https:/www.bmj.com/content/bmj/362/bmj.k2738.full.pdf.

73. Rieder H. Epidemiologic basis of tuberculosis control: International Union Against Tuberculosis and Lung Disease. Paris; 1999.

74. Grzybowski S. Drugs are not enough: failure of short-course chemotherapy in a district in India. Tuber Lung Dis. 1993;74(3):145-6.

75. Tiemersma EW, van der Werf MJ, Borgdorff MW, Williams BG, Nagelkerke NJ. Natural history of tuberculosis: duration and fatality of untreated pulmonary tuberculosis in HIV negative patients: a systematic review. PLoS One. 2011; 6(4):e17601 https://www.ncbi.nlm.nih.gov/pmc/articles/PMC3070694/pdf/ pone.0017601.pdf.

76. Menzies D, Benedetti A, Paydar A, Martin I, Royce S, Pai M, et al. Effect of duration and intermittency of rifampin on tuberculosis treatment outcomes: a systematic review and meta-analysis. PLoS Med. 2009;6(9):e1000146 https:// www.ncbi.nlm.nih.gov/pmc/articles/PMC2736385/pdf/pmed.1000146.pdf.

77. Stead LF, Perera R, Bullen C, Mant D, Hartmann-Boyce J, Cahill K, et al. Nicotine replacement therapy for smoking cessation. Cochrane Database Syst Rev. 2012. https://doi.org/10.1002/14651858.CD000146.pub4(11) https:// doi.org/10.1002/14651858.CD000146.pub4

78. Stead LF, Koilpillai P, Lancaster T. Additional behavioural support as an adjunct to pharmacotherapy for smoking cessation. Cochrane Database Syst Rev. 2015. https://doi.org/10.1002/14651858.CD009670.pub3(10) https://doi. org/10.1002/14651858.CD009670.pub3.

79. Levy DT, Hyland A, Higbee C, Remer L, Compton C. The role of public policies in reducing smoking prevalence in California: results from the California tobacco policy simulation model. Health policy. 2007;82(2):167-85 https:// www.ncbi.nlm.nih.gov/pmc/articles/PMC2743269/pdf/nihms25327.pdf.

80. Levy D, de Almeida LM, Szklo A. The Brazil SimSmoke policy simulation model: the effect of strong tobacco control policies on smoking prevalence and smokingattributable deaths in a middle income nation. PLoS Med. 2012:9(11):e1001336 https:/www.ncbi.nlm.nih.gov/pmc/articles/PMC3491001/pdf/pmed.1001336.pdf.

81. Friend $\mathrm{K}$, Levy DT. Reductions in smoking prevalence and cigarette consumption associated with mass-media campaigns. Health Educ Res. 2002;17(1):85-98.

82. Tan M, Menzies D, Schwartzman K. Tuberculosis screening of travelers to higherincidence countries: a cost-effectiveness analysis. BMC Public Health. 2008;8(1):201.

83. Service des relations avec la clientèle. List of Medications. RAMQ. Quebec: Bibliothèque et Archives nationales du Québec, 2017; 2017. p. 642. https:// www.ramq.gouv.qc.ca/en/citizens/prescription-drug-insurance/Pages/ prescription-drugs-covered.aspx.

84. Ontario Ministry of Health and Long-Term Care. Schedule of Benefits, Physician Services Under the Health Insurance Act: Ministry of Health and Long-Term Care, 2015. http://www.health.gov.on.ca/en/pro/programs/ohip/ sob/physserv/sob_master11062015.pdf.

\section{Ready to submit your research? Choose BMC and benefit from:}

- fast, convenient online submission

- thorough peer review by experienced researchers in your field

- rapid publication on acceptance

- support for research data, including large and complex data types

- gold Open Access which fosters wider collaboration and increased citations

- maximum visibility for your research: over $100 \mathrm{M}$ website views per year

At $\mathrm{BMC}$, research is always in progress.

Learn more biomedcentral.com/submissions 